\title{
Respon Beberapa Varietas Unggul Kedelai dan Kedelai Impor Terhadap Peronospora Manshurica Penyebab Penyakit Bulai (Downy mildew)
}

\author{
${ }^{1}$ Ani Ardiana Susanti, ${ }^{2}$ Husda Marwan, ${ }^{2}$ Mapegau, dan ${ }^{3}$ Marlina \\ ${ }^{1}$ Balai Karantina Pertanian Kelas I Jambi \\ Jl. MTQ Raya No. 1, Talang Bakung, Kec. Jambi Selatan Kota Jambi, Jambi 36135 \\ ${ }^{2}$ Jurusan Agroekoteknologi Fakultas Pertanian Universitas Jambi \\ J1. Raya Jambi - Ma. Bulian KM. 15 Kampus Pinang Masak, Mendalo Darat, 36361 \\ ${ }^{3}$ Jurusan Proteksi Tanaman Fakultas Pertanian Universitas Syiah Kuala \\ Jl. Tgk. Hasan Krueng Kalee No. 3 Kopelma Darussalam Banda Aceh \\ ${ }^{1}$ e-mail korenspondensi : ann_dewe@yahoo.co.id
}

\begin{abstract}
The attack of downy mildew in soybeans caused by the fungus Peronospora manshurica in Indonesia is still limited, but in soybean producing countries such as Brazil, America and China this disease has an important status that causes damage to $8-14 \%$. This study aims to determine the response of three superior varieties of soybean and imported soybean from Malaysia to Peronospora manshurica. The experiment was designed according to a completely randomized design (CRD) with 4 replications. The superior soybean varieties tested were Anjasmoro, Grobokan, Wilis, and imported soybeans. The variables observed included : time of emergence of trifoliate leaves, plant height, and leaf area. Observation data were analyzed descriptively and presented in tables and figures. The results showed that the three superior varieties of soybeans and imported soybeans tested showed differences in responding to the pathogenic fungus Peronospora manshurica. Anjasmoro, Grobogan, and imported soybean varieties responded with a faster rate of increase in plant height but with a slow rate of increase in leaf area. The Wilis variety responded to Peronospora manshurica with a slow rate of increase in plant height but with a faster rate of increase in leaf area. The first 100\% trifoliate leaves appeared at the age of 7 days after planting, except for the Grobogan variety, only $80 \%$ appeared.
\end{abstract}

Keywords: Soybean, downy mildew, Peronospora manshurica

\begin{abstract}
Abstrak. Serangan penyakit bulai (downy mildew) pada kedelai yang disebabkan oleh cendawan Peronospora manshurica di Indonesia masih terbatas, tetapi di negara-negara penghasil kedelai seperti Brazil, Amerika, dan China penyakit ini berstatus penting yang menyebabkan kerusakan $8-14 \%$. Penelitian ini bertujuan untuk mengetahui respon tiga varietas unggul kedelai dan kedelai impor asal Malaysia terhadap Peronospora manshurica. Percobaan dirancang menurut Rancangan Acak Lengkap (RAL) dengan 4 ulangan. Varietas unggul kedelai yang diuji adalah Anjasmoro, Grobokan, Wilis, dan kedelai impor. Peubah yang diamati meliputi : waktu munculnya daun trifoliate, tinggi tanaman, dan luas daun. Data hasil pengamatan dianalisis secara deskriptif dan disajikan dalam tabel dan gambar. Hasil penelitian menunjukkan bahwa tiga varietas unggul kedelai dan kedelai impor yang diuji menunjukkan perbedaan dalam merespon cendawan patogen Peronospora manshurica. Varietas Anjasmoro, Grobogan, dan kedelai impor merespon dengan laju pertambahan tinggi tanaman yang lebih cepat tetapi dengan laju pertambahan luas daun yang lambat. Varietas Wilis merespon Peronospora manshurica dengan laju pertambahan tinggi tanaman yang lambat tetapi dengan laju pertambahan luas daun lebih cepat. Daun trifoliat pertama $100 \%$ muncul pada umur 7 hari sesudah tanam kecuali pada varietas Grobogan baru muncul $80 \%$.
\end{abstract}

Kata kunci: kedelai, penyakit bulai, Peronospora manshurica

\section{PENDAHULUAN}

Kedelai memiliki prospek yang baik untuk dikembangkan sebagai bahan pangan dan pakan ternak karena nilai gizinya yang cukup baik dan sebagai sumber protein nabati yang relatif murah. Dalam biji kedelai terdapat 40 $\%$ protein, $20 \%$ minyak, $35 \%$ karbohidrat dan $5 \%$ abu. Disamping itu biji kedelai juga kaya akan asam lemak tak jenuh yaitu oleat, linoleat, asam folat, isoflavon, fosfor, besi, kalsium dan vitamin B (Sharma dan Baluja, 2015).

Seiring dengan semakin meningkatnya kesadaran masyarakat akan pentingnya makanan yang bernilai gizi tinggi dan jumlah penduduk yang terus meningkat dari tahun ketahun, maka kebutuhan kedelai juga meningkat setiap tahunnya. Lebih dari $18 \mathrm{~kg} / \mathrm{kapita} / \mathrm{tahun}$ jumlah kedelai yang harus dipenuhi untuk konsumsi masyarakat. Kebutuhan kedelai dalam negeri setiap tahunnya mencapai \pm 2 juta ton, sedangkan produksi baru mencapai 800 ribu ton atau sekitar 40\% dari kebutuhan ( Deptan 2008 dalam Destasari, Suharyono dan Yulianto, 2015 ). Untuk memenuhi kebutuhan kedelai di Indonesia sejauh ini ditempuh dengan cara impor yang diperkirakan pada tahun 2020 mencapai 3.398.008 (Aimon dan Satrianto, 2014).

Salah satu penghambat dalam peningkatan produksi kedelai adalah serangan penyakit yang disebabkan oleh cendawan patogen. Cendawan patogen menjadi penting karena kisaran serangannya sangat luas (Martoredjo 1984). Salah satu cendawan patogen yang dapat terbawa biji kedelai impor adalah cendawan Peronospora manshurica penyebab penyakit bulai (downy mildew) pada kedelai. Cendawan ini merupakan cendawan seed borne.( Roongruangsree, Olson, dan Lange, 2008; Pap, Milosevic, dan Jasnic, 2007). Penyakit bulai pada kedelai merupakan 
penyakit berstatus penting dibeberapa negara penghasil kedelai seperti Brazil, Amerika, dan China dengan tingkat kerusakan sebesar 8 - 14 \% (Silva, Santos, Pria, dan Mio., 2016). Di Indonesia sendiri keberadaan penyakit ini masih terbatas di Jawa Timur dan Jawa Barat. Di Jawa Timur intensitas serangan Peronospora manshurica mencapai 30,28\%, sehingga dinyatakan sebagai penyakit dengan status penting (Budiarti dan Pustika., 2012).

\section{Tempat dan waktu}

\section{METODE PENELITIAN}

Penelitian ini dilakukan di laboratorium Mikologi Balai Karantina Pertanian (BKP) Kelas I Jambi dan di rumah kaca BKP kelas I Jambi. Penelitian dilakukan mulai bulan Mei sampai dengan bulan November 2018.

\section{Bahan dan alat}

Biji kedelai impor, biji kedelai varietas Anjasmoro, Grobogan dan Wilis, tanah, pupuk kandang, sekam, polybag. sekop, cangkul, ember, meteran, plastik, dan inokulan cendawan patogen Peronospora manshurica yang diperoleh dari Balai Karantina Pertanian Klas I Jambi.

\section{Rancangan Percobaan}

Penelitian ini menggunakan Rancangan Acak Lengkap (RAL) dengan 3 varietas unggul kedelai dan satu kedelai impor yang diuji responnya terhadap cendawan Peronospora manshurica penyebab penyakit bulai (Downy mildew) sebagai berikut :

$$
\begin{aligned}
& \text { Anjasmoro }+1000 \text { oospora/ml } \\
& \text { Grobokan }+1000 \text { oospora/ml } \\
& \text { Wilis }+1000 \text { oospora } / \mathrm{ml} \\
& \text { Impor }+1000 \text { oospora } / \mathrm{ml}
\end{aligned}
$$

Setiap perlakuan diulang 6 kali sehingga diperoleh 24 unit percobaan dengan masing-masing percobaan terdiri dari 5 tanaman sehingga diperoleh jumlah tanaman sebanyak 120 tanaman. Data hasil pengamatan dianalisis secara deskriptif dan disajikan dalam tabel dan gambar.

\section{Peubah yang Diamati}

1. waktu munculnya daun trifoliate (hari setelah tanam). Jumlah daun trifoliate yang muncul kemudian dikonversi menjadi persentase $(\%)$

2. tinggi tanaman $(\mathrm{cm})$. Pengukuran dilakukan sebelum perlakuan pada umur 14 hari setelah tanam dan setelah perlakuan pada umur 21 hari setelah tanam

3. luas daun $\left(\mathrm{cm}^{2}\right)$. Pengukuran dilakukan sebelum diinokulasi dengan cendawan Peronospora manshurica (umur 14 hari sesudah tanam) dan umur tanaman 21 hari sesudah tanam

\section{Persiapan media tanam dan persiapan penanaman}

Media tanam untuk penanaman kedelai disiapkan 2 minggu sebelum tanam. Pembuatan media tanam dilakukan dengan meyiapkan campuran tanah, pupuk kandang dan sekam padi dengan perbandingan 1:1:1. Semua bahan dicampur menjadi satu dan dilakukan pengayakan untuk membuang batu, seresah atau sampah.Tanah yang telah homogen kemudian dimasukan ke dalam polybag ukuran $10 \mathrm{~kg}$, selanjutnya polybag yang telah berisi media tanam diletakan sesuai dengan tata letak percobaan dengan jarak antar polybag $25 \mathrm{~cm}$ x $30 \mathrm{~cm}$.

Benih kedelai ditanam pada polybag yang telah berisi media tanam. Penanaman benih kedelai dilakukan dengan cara membuat lubang pada media tanam dengan kedalaman $3 \mathrm{~cm}$, kemudian membenamkan biji kedelai pada lubang yang telah dibuat dengan mengisi tiap lubang 3 biji tanaman kedelai dengan jarak tanam 30 x $30 \mathrm{~cm}$. Setelah kedelai tumbuh dilakukan penjarangan pada setiap polybag dengan meyisakan 1 tanaman yang mempunyai pertumbuhan paling baik.

\section{Inokulasi}

Inokulasi dilakukan pada kedelai yang berumur 14 hari setelah tanam dan dilakukan pada sore hari sekitar pukul 17.00 WIB. Inokulasi dilakukan dengan cara menyemprotkan suspensi patogen ke daun kedelai sehat. Daun tanaman muda disemprot dengan 1000 oospora/ml suspensi, kemudian disebarkan secara merata keseluruhan daun. Untuk mendapatkan kelembaban yang tinggi, polybag dilapisi dengan karung goni basah dan tanaman disungkup dengan kain setelah perlakuan. Tiga hari setelah perlakuan kain penutup dibuka. 


\section{Munculnya daun trifoliate pertama}

\section{HASIL DAN PEMBAHASAN}

Daun kedelai mempunyai dua bentuk daun yaitu stadia kotiledon yang tumbuh saat tanaman masih berbentuk kecambah dengan dua helai daun tunggal dan daun bertangkai tiga (daun trifoliate) yang tumbuh selepas masa pertumbuhan. Pada penelitian ini daun trifoliat muncul rata-rata pada 7 hari setelah tanam. Dalam hal ini belum diinokulasi dengan cendawan pathogen Peronospora manshurica. Persentase dan waktu kemunculan daun trifoliat dapat dilihat pada Tabel 1.

Tabel 1. Persentase dan waktu kemunculan daun trifoliat pertama pada varietas Anjasmoro, Grobagan, Wilis, dan kedelai Impor

\begin{tabular}{clcc}
\hline No & Varietas & Kemunculan daun trifoliat $(\%)$ & $\begin{array}{c}\text { Kemunculan daun trifoliate } \\
\text { (HST) }\end{array}$ \\
\hline 1 & Anjasmoro & 100 & 7 \\
2 & Grobogan & 80 & 7 \\
3 & Wilis & 100 & 7 \\
4 & Import & 100 & 7 \\
\hline
\end{tabular}

Tabel 1 di atas menunjukkan bahwa daun trifoliat pertama pada tiga varietas kedelai unggul dan kedelai impor muncul dalam waktu yang bersamaan yaitu pada hari ke 7 atau pada saat tanaman berumur 7 hari setelah tanam. Persentase tingkat kemunculan pada varietas Anjasmoro, Wilis, dan kedelai impor yaitu 100\% sedangkan pada varietas Grobogan sebesar 80\%. Lebih jauh dapat ditafsirkan bahwa ketiga varietas kedelai dan kedelai impor yang diuji responnya terhadap Peronospora manshurica penyebab penyakit bulai (downy mildew) mempunyai kecepatan atau keseragaman tumbuh yang sama.

\section{Tinggi tanaman}

Hasil penelitian menunjukkan bahwa terdapat perbedaan tinggi tanaman antara varietas Anjasmoro, Grobogan, Wilis, dan kedelai Impor yang diuji responnya terhadap Peronospora manshurica . Tinggi tanaman yang diperoleh dari dua kali pengamatan yaitu sebelum perlakuan pada umur 14 hari setelah tanam dan setelah perlakuan pada umur 21 hari setelah tanam dapat dilihat pada Gambar 1. Meskipun demikian, perbedaan tinggi ini belum menggambarkan respon sesungguhnya, karena semua varietas ini mempunyai karakter tinggi yangrelatif berbeda.

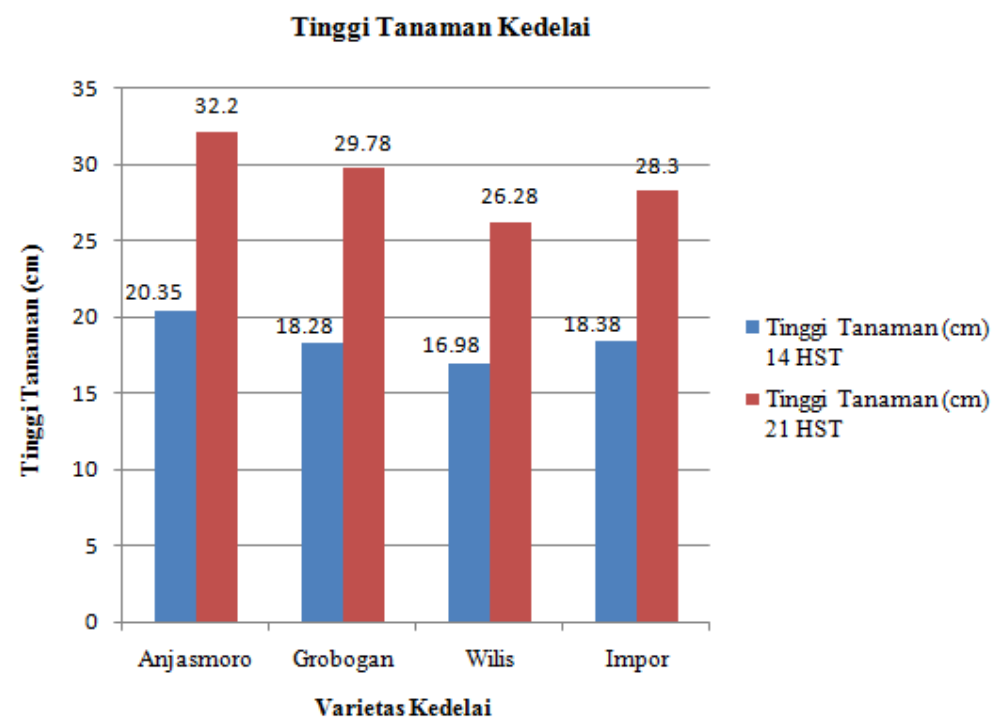

Gambar 1. Tinggi tanaman kedelai varietas Anjasmoro, Grobogan, Wilis dan Kedelai Impor pada umur14 hari sesudah tanam dan 21 hari sesudah tanam.

Tinggi tanaman terendah diperoleh pada varietas Wilis yaitu $16.98 \mathrm{~cm}$ pada umur14 hari setelah tanaman dan $26,28 \mathrm{~cm}$ pada umur 21 hari setelah tanaman. Tinggi tanaman tertinggi diperoleh pada varietas Anjasmoro yaitu $20,35 \mathrm{~cm}$ pada umur 14 hari setelah tanam dan $32,2 \mathrm{~cm}$ pada umur 21 hari setelah tanam. Selanjutnya varietas Grobogan dengan tinggi 18,28 cm pada umur 14 hari sesudah tanam dan 29,78 cm pada umur 21 hari sesudah tanam, disusul kemudian kedelai impor dengan tinggi $28,38 \mathrm{~cm}$ pada umur 14 hari sesudah tanam dan $28,30 \mathrm{~cm}$ pada umur 21 sesudah tanam. 
Perbedaan respon antara varietas Anjasmoro, Grobogan, Wilis, dan kedelai impor terhadap cendawan pathogen Peronospora manshurica penyebab penyakit bulai (downy mildew), lebih lanjut dapat ditelusuri melalui perbedaan laju pertambahan tinggi tanaman. Berdasarkan data yang tertera pada Gambar 1,.dapat diketahui bahwa dalam kurun waktu satu minggu, laju pertambahan tinggi tanaman pada varietas Anjasmoro 1,69 $\mathrm{cm}$ per hari, varietas Grobogan 1,64 cm per hari, kedelai impor 1,42 cm per hari, dan laju pertambahan tinggi terendah diperoleh pada varietas Wilis yaitu $1,33 \mathrm{~cm}$ per hari.

\section{Luas daun}

Luas daun tiga varietas kedelai dan kedelai impor sebelum diinokulasi dengan cendawan pathogen Peronospora manshurica (umur 14 hari sesudah tanam) relatif sama. Perbedaan luas daun mulai jelas terlihat pada umur tanaman 21 hari sesudah tanam yaitu 7 hari sesudah inokulasi cendawan pathogen Peronospora manshurica (Gambar 2). Daun terluas diperoleh pada varietas Wilis $\left(20,71 \mathrm{~cm}^{2}\right)$, disusul kemudian varietas Anjasmoro $(17,97$ $\left.\mathrm{cm}^{2}\right)$, dan varietas Grobogan $\left(16,90 \mathrm{~cm}^{2}\right)$. Luas daun terendah diperoleh pada Kedelai Impor $\left(14,77 \mathrm{~cm}^{2}\right)$

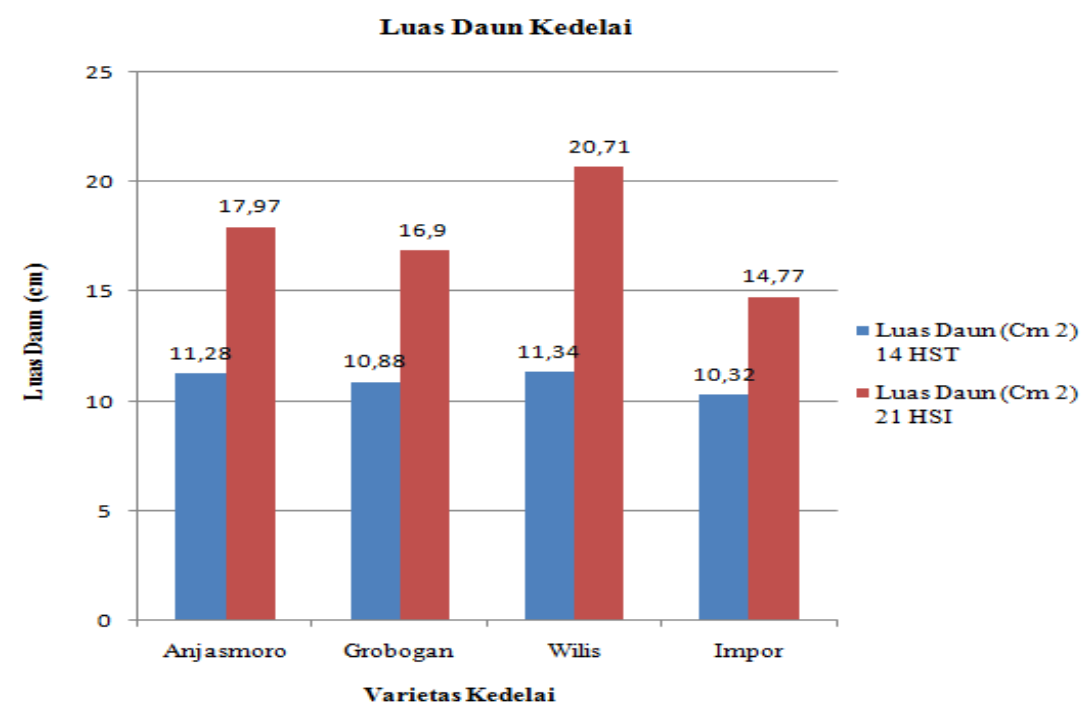

Gambar 2. Luas daun tanaman kedelai varietas Anjasmoro, Grobogan, Wilis,dan Kedelai Impor pada umur14 hari sesudah tanam dan 21 hari sesudah tanam.

Berdasarkan data luas daun pada Gambar 2, dapat dihitung laju pertambahan luas daun pada tiga varietas kedelai dan kedelai impor dalam merespon Peronospora manshurica. Laju pertambahan luas daun tertinggi diperoleh pada varietas Wilis $\left(1,34 \mathrm{~cm}^{2}\right)$, diikuti kemudian varietas Anjasmoro $\left.0,96 \mathrm{~cm}^{2}\right)$, varietas Grobogan $(0,86$ $\left.\mathrm{cm}^{2}\right)$, dan pertambahan luas daun terkecil diperoleh pada Kedelai Impor $\left(0,64 \mathrm{~cm}^{2}\right)$ per hari.

\section{KESIMPULAN}

Tiga varietas unggul kedelai dan kedelai impor yang diuji menunjukkan perbedaan dalam merespon cendawan patogen Peronospora manshurica penyebab penyakit bulai. Varietas Anjasmoro, Grobogan, dan kedelai impor merespon dengan laju pertambahan tinggi tanaman yang lebih cepat tetapi dengan laju pertambahan luas daun yang lambat. Varietas Wilis merespon Peronospora manshurica dengan laju pertambahan tinggi tanaman yang lambat tetapi dengan laju pertambahan luas daun lebih cepat.

Daun trifoliat pertama varietas Anjasmoro, Wilis, dan kedelai impor muncul 100\% pada umur 7 hari sesudah tanam tetapi varietas Grobogan baru muncul $80 \%$.

\section{DAFTAR PUSTAKA}

Aimon, H., Satrianto, A. 2014. Prospek Konsumsi dan Impor Kedelai Indonesia tahun 2015-2020. Jurnal Kajian Ekonomi. 3 (5).

Agarwal, P.C. Singh, U.D.B., Indra, R. dan Khetarpal, R.K. 2006. Seed Borne Fungi Detected in Consignments of Soybean Seeds (Glycine max) Imported into India. EPPO Bulletin. 36 : 53-58

Budiarti, S.W., dan Pustika, A.B. 2012. Kajian tingkat ketahanan beberapa varietas kedelai terhadap penyakit Downy mildew (Peronospora manshurica). Balai Perlindungan Tanaman Pangan dan Hortikultura. Yogyakarta 
Destasari, A., M., Suharyono dan Yulianto, E., 2015.Pengaruh produki kedelai dalam negeri dan harga kedelai dunia terhadap volume impor kedelai di Indonesia (Studi terhadap volume import kedelai tahun 1996-2013). Jurnal Administrasi Bisnis. Volume 1 no.1

Pap., S., M., Milosevic, M., dan Jasnic, S., 2007. Soybean Seed Borne Fungi in the Vojvodina Province. Phytopathol. $45: 55-65$

Roongruangsree, U.T., L.W Olson, dan Lange, L. 2008. The seed borne inoculum of Peronospora manshurica, causal agent of soybean downy mildew. Jurnal Phytopathology. 123(3). Paul Parey Scientific Publisher.

Sharma, A., dan Baluja, Z. , 2015. Therapeutic Effects of Glycine max (soybean). International Journal of Research in Pharmacy and Biosciences. 2: 22-27

Silva, O.C.D., Santos, H.A.A., Pria, M.D., dan Mio, L.L.M.D., 2016. Damage to Soybean Caused by Downy mildew. Ciencia Rural.46 (3). Maret 2016 